\title{
Eco-Friendly Process of Absorbent Cotton Preparation for Rural Entrepreneurship
}

\author{
P. Jagajanantha*, V. Mageshwaran, Varsha Satankar and P.G. Patil
}

ICAR-Central Institute for Research on Cotton Technology, Mumbai-400019, India

*Corresponding author

\begin{tabular}{|l|}
\hline K e y w o r d s \\
$\begin{array}{l}\text { Eco-friendly method, } \\
\text { Absorbent Cotton, Enzymatic } \\
\text { Scouring, Bleaching, Banana } \\
\text { Pseudo stem, Cotton seed } \\
\text { hull, Cotton seed meal }\end{array}$ \\
\hline Article Info \\
\hline $\begin{array}{l}\text { Accepted: } \\
\text { 06 May } 2018 \\
\text { Available Online: } \\
\text { 10 June } 2018\end{array}$ \\
\hline
\end{tabular}

\section{Introduction}

Absorbent cotton also known as surgical cotton or cotton wool which is mainly used for medical purposes in hospitals, nursing homes, dispensaries etc. (Gayal, 2012; Vassiliadis et al., 2012). Because of high fluid absorbency power, it is generally called as absorbent cotton (Panja et al., 2014; Raja et al., 2016). Absorbent cotton is cleaned, scoured and bleached cotton used for various applications like wound dressing, surgical operation, dental plugs, face wipes, ear buds etc. (Kadam, 2012). As absorbent cotton is in direct contact
A combined scouring and bleaching process was developed for absorbent cotton preparation using crude enzyme. The substrate for crude enzyme preparation includes banana pseudo stem dry powder, cotton seed hulls and cotton seed meal in the ratio of 60:30:10. The crude enzyme was extracted from the fermented substrate and the pectinase and laccase activity recorded in the enzyme extract was 25 and 7 Units per $\mathrm{ml}$ respectively. Experimental trials were taken to prepare absorbent cotton from one $\mathrm{kg}$ of short staple cotton (var. Phule Dhanwantry) using High Temperature and High Pressure (HTHP) method and Open Bath (OB) method. The process conditions were cotton fibre and crude (9.0) and wetting agent $(0.1 \%)$. The absorbency recorded was 3 seconds (sink test) and whiteness index of 32(CIE standard) and 41 in HTHP and OB methods HTHP method. Considering the large availability of cheap agro residue in the rural places, this eco-friendly, economical and simple enzymatic process could be easily adopted for rural entrepreneurship development, especially for rural women employment. 
(Karapinar and Sariisik, 2004). To convert them into hydrophilic in nature, the fibres were treated using sodium hydroxide for scouring and hydrogen peroxide for bleaching (Mojsov, 2012; Meena et al., 2016).

The sodium hydroxide helps to remove the hydrophobic substances on the cotton fibre by saponification followed by emulsification which is known as scouring and the hydrogen peroxide helps to whiten the cotton fibre through oxidation, which is known as bleaching (Tzanov et al., 2001). In the existing absorbent cotton preparation, higher concentration of sodium hydroxide is used which is harmful to environment and pollutes the agricultural land (Hasan et al., 2015; Shrimali and Dedhia, 2013). In this study, an attempt was made to produce crude enzyme from agro-residue and subsequently used to convert short staple cotton into absorbent cotton in an eco-friendly manner.

\section{Materials and Methods}

\section{Cotton fibre}

The cotton fibre (PhuleDhanwantry variety) was procured from Central Institute for Cotton Research, Nagpur and the same was used throughout the work (Meena et al., 2016). As a preparatory process, the cotton fibre was opened through trash separator to remove unwanted particles in the fibre. The fibre quality of procured cotton was Strength (16.3 $\mathrm{g} /$ tex), Length (20.8 mm), Micronaire (6.3) and whiteness index (16.3)

\section{Substrates for solid state fermentation}

The agro waste like banana pseudo stem, cottonseed hulls and cottonseed meal were used as substrates for solid state fermentation. These substrates (banana pseudo stem, cottonseed hulls and cottonseed meal) were dried in sunlight, powdered and passed through $1 \mathrm{~mm}$ sieve and then taken for solid state fermentation in the proportion of (60:30:10) respectively.

\section{Microorganisms used}

The test fungal strain, Pleurotus flabellatus was grown in malt extract broth $(1 \mathrm{X})$ at $30^{\circ} \mathrm{C}$ for 48 hours and maintained in malt extract agar slant at $4^{\circ} \mathrm{C}$ and used.

\section{Solid state fermentation}

The mixed substrate $(1.2 \mathrm{~kg})$ was taken in the ratio as detailed before and autoclaved at $121^{\circ} \mathrm{C}$ for $15 \mathrm{~min}$ at $15 \mathrm{lbs} / \mathrm{in}^{2}$. The autoclaved substrate was taken in disinfected plastic tray, cooled and inoculated with 5\% P. flabellatus culture suspension, incubated for 5 days at room temperature $\left(28 \pm 5^{\circ} \mathrm{C}\right)$.

\section{Enzyme extraction}

The fermented substrate (Fig. 1) as depicted was mixed with ten liters of pure water $(\mathrm{pH} 7)$ and the extracellular enzyme was extracted by stirring for 10 minutes and filtered through muslin cloth. The enzyme extract was stored at $4^{\circ} \mathrm{C}$ until use. The crude enzyme (Fig. 2) was used for subsequent scouring and bleaching treatment.

\section{Pectinase and laccase assay}

The pectinase and laccase activity were estimated in crude enzyme extract (Reynolds et al., 2018). The pectinase activity was determined by estimation of polygalactouronase activity and analysis of reducing sugars released from citrus pectin during the reaction. One unit of enzymatic activity (U) was defined as the amount of enzyme which released one $\mu \mathrm{mol}$ of galactouronic acid per minute. Laccase activity was estimated using syringaldazine as substrate (Sigma-Aldrich [EC 1.10.3.2]). One 
unit of enzyme activity (U) was defined as change in absorbance $(530 \mathrm{~nm})$ of 0.001 per min at $\mathrm{pH} 6.5$ at $30^{\circ} \mathrm{C}$.

\section{Experimental trials}

\section{Enzymatic scouring and bleaching using HTHP method}

One $\mathrm{kg}$ of cotton fibres wetted out in $0.1 \%$ non-ionic wetting agent before loading into the machine. This assures the uniform processing of material in the HTHP machine (Fig. 3). While loading the cotton fibres into the perforated carrier, care was taken to make uniform damping into the vessel. Then the machine was programmed to automatic processing and the below given steps were followed.

\section{Enzymatic scouring and bleaching using OB method}

In this method, the cotton fibres taken were taken into a stainless steel vessel (30 liters capacity) to which 12 liters of crude enzyme was added. To maintain 1:20 cotton fibre to liquid ratio, an additional 8 liters of water was added. The $\mathrm{pH}$ in the bath was maintained at 9 using diluted $\mathrm{NaOH}$ solution. Wetting agent $(0.1 \%)$ was added to have uniform mixing of cotton in water. The temperature was increased using Liquid Petroleum Gas (LPG) stove and maintained $55 \pm 3^{\circ} \mathrm{C}$ for $40 \mathrm{~min}$. Once the process was completed, the absorbent cotton was washed, squeezed and dried. The dried sample was tested for absorbent cotton tests as per Indian Pharmacopeia standards.

\section{Results and Discussion}

Solid state fermentation an process in which microbial growth and products formation occur on the surfaces of solid substrates in the near absence of free water (Martin et al.,
2004). In this study, attempt was made to prepare crude enzyme for absorbent cotton treatment using locally available agroresidues. The agro-substrates such as banana pseudo stem, cottonseed hulls and cottonseed meal in the ratio of 60:30:10 was used for crude enzyme preparation. The crude enzyme was extracted five days after solid state fermentation. The pectinase and laccase activity in the crude enzyme was found to be 25 and 7 units/ml respectively (Fig. 4). Solid state fermentation is extensively used for isolation of enzymes and other bio-products for industrial applications. Among the different substrates, agro-residues are the cheapest and largely available source for production of industrially used enzymes especially pectinase and laccase enzymes. The pectinase and laccase enzymes are used for scouring and bleaching process respectively (Tzanov et al., 2001; Pereira et al., 2005).

The raw cotton contains $94 \%$ cellulose and $6 \%$ of non-cellulosic impurities. The pectin and the waxes are the major impurities present in cotton (Spicka and Tavcer, 2013). Pectin substances binds waxes on the outer layer of fibre are responsible for non-absorbent characteristics of cotton (Rita et al., 2008; Vassiliadis et al., 2012; Panja et al., 2014). The use of commercial pectinase enzymes for absorbent cotton preparation is well reported (Tznov et al., 2001; Karapinar and Sariisik, 2004; Spicka and Tavcer, 2013). In this study, the effect of crude enzyme on preparation of absorbent cotton was evaluated.

The results of our previous experiments revealed that the optimized process parameters under shaking water bath conditions for absorbent cotton treatment using crude enzyme were, cotton fibre and crude enzyme ratio $1: 12$, material to liquor ratio 1:20, temperature $\left(55^{\circ} \mathrm{C}\right)$, time (40 min), $\mathrm{pH}(9.0)$ and wetting agent $(0.1 \%)$ (results not published). 
Fig.1 Solid-state fermentation

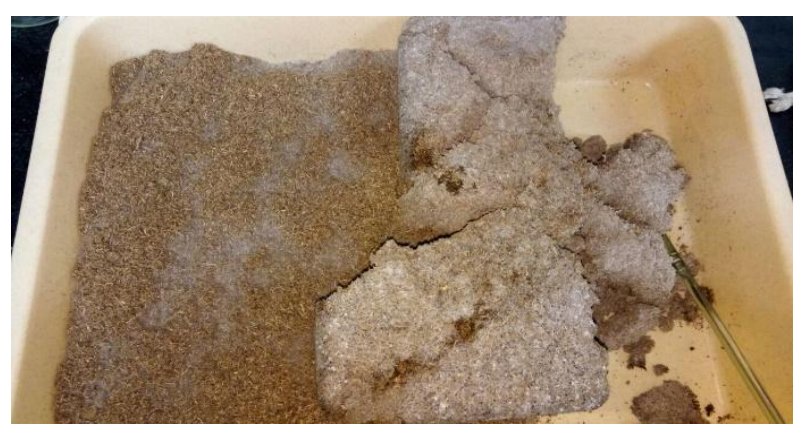

Fig.2 Enzyme extract

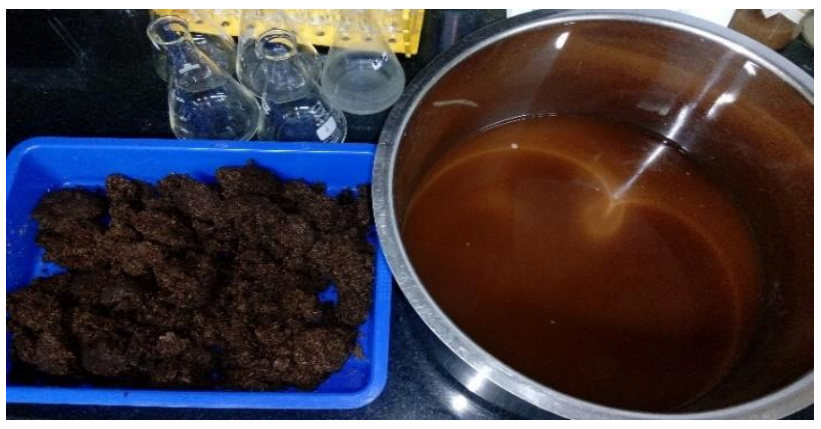

Fig.3 High Temperature and High Pressure (HTHP) machine

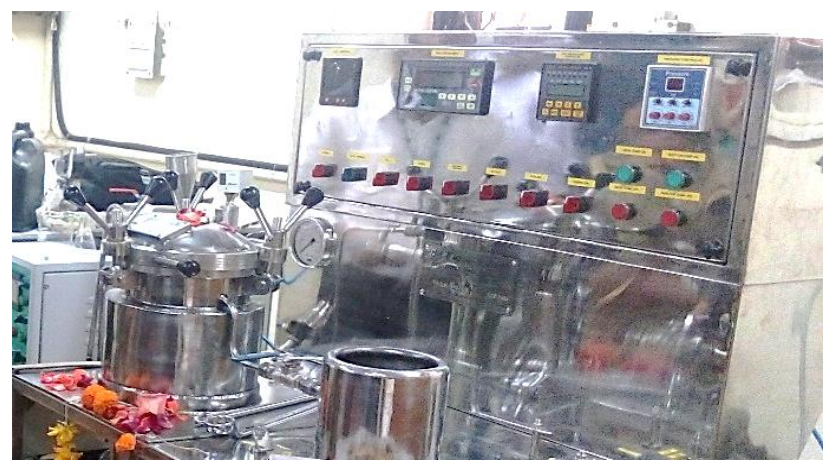

Fig.4 Enzyme activity in crude extract

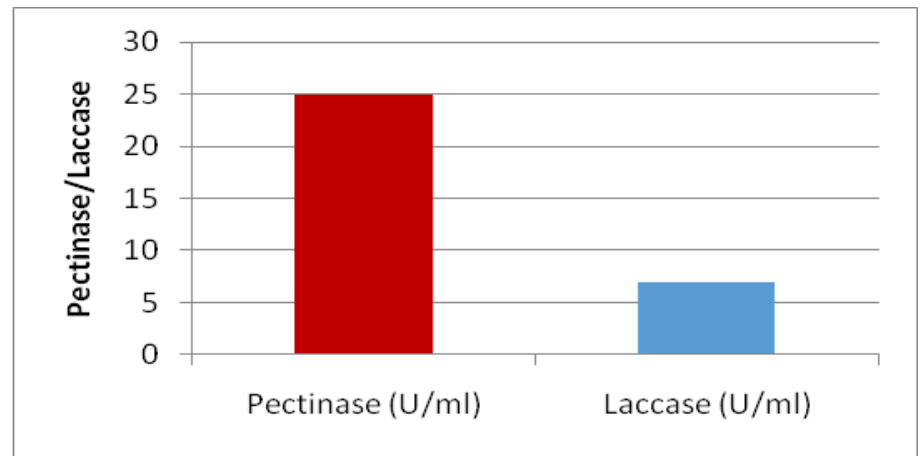


The dried sample was tested for absorbent cotton tests as per Indian Pharmacopeia standards

Filled the machine with 12 liters of crude enzyme

Added8 liters of water to maintain 1: 20 cotton fibre to liquor ratio

Slowly added the diluted $\mathrm{NaOH}$ to reach the $\mathrm{pH} 9$

Raised the temperature to $55^{\circ} \mathrm{C} @ 1{ }^{\circ} \mathrm{C} / \mathrm{min}$<smiles>C1=CC=C1</smiles>

Circulated the liquor in-out \& out-in<smiles>C1C2CC1C2</smiles>

Continued to run the machine for 40 minutes after reaching $55^{\circ} \mathrm{C}$

Drained and filled it again with water<smiles>C1=CC=C1</smiles>

Cold wash \&hot wash were carried out as after treatment<smiles></smiles>

Hydro extracted to remove excess water and dried

Table.1 Properties of enzymatically processed absorbent cotton

\begin{tabular}{|c|c|c|c|}
\hline \multirow{2}{*}{ Parameter } & \multicolumn{2}{|c|}{ Treated } & $\begin{array}{c}\text { Standard } \\
\text { (Indian }\end{array}$ \\
\cline { 2 - 4 } & $\begin{array}{c}\text { High Temperature } \\
\text { High Pressure method }\end{array}$ & $\begin{array}{c}\text { Open Bath } \\
\text { method }\end{array}$ & $\begin{array}{c}\text { Pharmacopeia) } \\
\text { Absorbency in seconds (Sink Test) }\end{array}$ \\
$\begin{array}{c}\text { Whiteness Index (as per CIE } \\
\text { method) }\end{array}$ & 3 & 3 & $<10$ \\
\hline $\begin{array}{c}\text { Sulphated Ash Content (\%) } \\
\text { Residual Wax Content }(\%)\end{array}$ & 0.20 & 0.22 & $<0.5$ \\
\hline Water Holding Capacity $(\mathrm{g} / \mathrm{g})$ & 0.066 & 0.075 & $<0.1$ \\
\hline
\end{tabular}

In the present study, experimental trials were taken under HTHP and OB methods for absorbent cotton treatment using crude enzyme under similar optimized conditions. The results of properties of absorbent cotton prepared under HTHP and OB methods were compared with standard for absorbent cotton. As per Indian Pharmacopeia, the major parameters taken into account are absorbency, whiteness index, water holding capacity, residual wax content and sulphated ash and the corresponding values are $<10,60,>23$, 
$<0.1$ and $<0.5$ respectively (Meena et al., 2016). The results showed that the properties of absorbent cotton prepared through HTHP and OB methods meet the Indian Pharmacopeia standards (Table 1) except whiteness index. The whiteness index was higher in HTHP absorbent cotton (41) than OB absorbent cotton (32) however, both the values were lower than standard. The whiteness index is mostly considered for subjective evaluation than quantitative. For example, the whiteness index is not a major determinant in sanitary napkins application. In a similar study, (Raja et al., 2016) reported that enzymatic scouring and bleaching of cotton is a viable alternative method to conventional alkali method which helps in significant reduction in release of toxic chemicals in to the environment.

In general, the absorbent cotton processed through HTHP and OB methods were not giving much variation on the physical characteristics of final product. But there are few differences on processing methods. The production capacity is higher in HTHP method and it is more viable for industrial production of absorbent cotton. But the capital investment on land, building and equipment (bleaching, hydro extracting, wet opening and drying) cost is higher. For example, the capital investment required for processing $100 \mathrm{~kg}$ short staple cotton per day is Rs. 5 lakh. On the other hand, OB can be suitable for village level preparation of absorbent cotton. The capital investment required for processing $100 \mathrm{~kg}$ short staple cotton per day is Rs. 50,000/-. The net profit could be earned through processing $100 \mathrm{~kg}$ of short staple cotton per day is Rs. 5000/-. Though, it is a time consuming process where the treatment, washing, squeezing and drying was done manually, the method offers a viable entrepreneurship at rural level especially for rural women employment. Since, the process does not involve heavy work and the materials required for processing are locally available.

The crude enzyme for absorbent cotton treatment was prepared using locally available agro-residues such as banana psuedostem, cottonseed hulls and cottonseed meal.

The absorbent cotton was prepared using crude enzyme under HTHP and OB methods.

The quality parameters of absorbent cotton prepared in the study, meets the IP standards.

Considering, the large availability of agroresidues for enzyme preparation and low initial investment, the OB method of absorbent cotton preparation would have application in rural entrepreneurship development.

The eco-friendly process of absorbent cotton preparation reduces the environmental pollution that may arise due to use of alkali.

\section{References}

Gayal, S. G., Nagarkar, R. D., Kambli, N. D., Kadam, R. P. 2012. Ecofriendly absorbent cotton from non spinnable fibres. Journal of Cotton Research and Development, 26(2). 267-271.

Hasan, M., Nabi, F and Mahmud, R. 2015. Benefits of Enzymatic Process in Textile Wet Processing. International Journal of Fiber and Textile Research, 5(2): 16-19.

Kadam, R.P. 2012. Eco-friendly absorbent cotton from non-spinnable fibres. Journal of Cotton Research \& Development, 26: 267-271.

Karapinar, E. and Sariisik, M.O. 2004. Scouring of Cotton with Cellulases, Pectinases and Proteases. Fibres and Textiles in Eastern Europe, 12, 3(47): 79-82. 
Martin, N., Regina de Souza, S., Roberto da Silva and Gomes, E. 2004. Pectinase Production by Fungal Strains in SolidState Fermentation Using AgroIndustrial Bioproduct, Brazilian Archives of Biology and Technology, 47, 5: 813-819.

Meena, R.A., Monga, D., Venugoplan, M.V., Ahuja, S.L. and Sahay, R. 2016. Screening of desi cotton (G. arboreum) suitable for surgical properties. Journal of Scientific and Industrial Research, 75: 570-573.

Mojsov, K. 2012. Enzyme Scouring of Cotton Fabrics: A review, International Journal of Technology Marketing, 2(9): 256-275.

Panja, S., Majumder, P., Sarkar, B. K., Mukim, K. K. and Hati, A. 2015. Global Research on Medical Cotton Evidence from Patent Landscape Study, Journal of Intellectual Property Rights, 20. 39-50.

Pereira, L., Bastos, C., Tzanov, T., CavacoPaulo, A. and Guebitz G.M., (2005), Environmentally friendly bleaching of cotton using laccasses. Eniviron. Chem. Lett., 3: 66-69.

Raja, A.S.M., Arputharaj, A., Saxena, S. and Patil, P.G. 2016. A one bath chemoenzymatic process for preparation of absorbent cotton. Perspectives in Science, 8: 254-256.

Reynolds, A. G., Knox, A. and Profio, F. D., 2018. Evaluation of Macerating Pectinase Enzyme Activity under Various Temperature, $\mathrm{pH}$ and Ethanol Regimes, Beverages 2018, 4, 10; 1-14.

Rita, A., Margarida, C. and Artur, C. 2008. Application of enzymes for textile fibres processing, Biocatalysis and Biotransformation, 26(5): 332 - 349.

Shrimali, K. and Dedhia, E. 2016. Enzymatic Finishing of Textiles. International Journal of Science and Research, 5(5): 674-677.

Spicka, N. and Tavcer, P.F. 2013. New Combined Bio-Scouring and BioBleaching Process of Cotton Fabrics. Materials and Technology, 47 (4), 409412.

Tzanov, T., Margarita C., Georg M. Guebitz., and ArturCavaco-Paulo. 2001. Biopreparation of cotton fabrics, Enzyme and Microbial Technology, 29 357-362.

Vassiliadis, S., D. Matsouka, C. Boutris, Cay A. 2011. Conformation and Suitability of the Commercially Available Absorbent Cotton Wool. International Congress on Healthcare and Medical Textiles.

\section{How to cite this article:}

Jagajanantha, P., V. Mageshwaran, Varsha Satankar and Patil, P.G. 2018. Eco-Friendly Process of Absorbent Cotton Preparation for Rural Entrepreneurship. Int.J.Curr.Microbiol.App.Sci. 7(06): 1097-1103. doi: https://doi.org/10.20546/ijcmas.2018.706.130 